\title{
П.С. Гущеров*
}

Тихоокеанский научно-исследовательский рыбохозяйственный центр, 690091, г. Владивосток, пер. Шевченко, 4

\section{ХАРАКТЕРИСТИКА ДЫХАТЕЛЬНОГО РИТМА БЕЛУХ (DELPHINAPTERUS LEUCAS) В УСЛОВИЯХ НЕВОЛИ}

На материалах 2009-2012 гг. рассмотрены параметры внешнего дыхания у белух, содержащихся в условиях неволи. Установлено, что в первые дни после отлова у белух наблюдается паттерн дыхания, характеризующийся низкими значениями показателей - частоты дыхания и апноэ (соответственно 2,2 $\pm 0,3$ дых./мин, 1,7 мин). В течение последующих 10-34 дней показатели параметров внешнего дыхания приближаются к норме (частота дыхания - 3,0 0 0,2 дых./мин, апноэ - 5,1 мин). Также выявлена зависимость частоты дыхания животных от их двигательной активности, определены некоторые различия в частоте дыхания и апноэ у белух разного возраста. Установлено, что влияние на частоту дыхания белух оказывает температура воды. Помимо всего прочего, проведенные исследования подтверждают, что дыхание белух в утренние часы несколько учащено по сравнению с вечерним временем.

Ключевые слова: белуха, условия неволи, частота дыхания, дыхательная пауза, двигательная активность.

Gushcherov P.S. Description of respiratory rhythm for white whales (Delphinapterus leucas) in captivity // Izv. TINRO. — 2016. — Vol. 185. — P. 123-131.

Parameters of external respiration are considered for white whales Delphinapterus leucas living in captivity on the observations in 2009-2012. Low respiration rate (on average $2.2 \pm 0.3$ breath per minute) and short apnea phase (no more than 1.7 minutes) were observed in the first days after the catch, but both parameters returned to normal values $(3.0 \pm 0.2$ breath per minute, apnea up to 5.1 minutes) in the next 10-34 days. The respiration rate in the morning is higher in comparison with the evening. The respiration rate dependence on the whales motor activity, their age, and water temperature is discussed, as well.

Key words: white whale, captivity, respiration rate, apnea, motor activity.

\section{Введение}

Белуха Delphinapterus leucas Pallas, 1776 распространена практически по всему полярному кругу Северного полушария, а также в дальневосточных морях, в том числе в Охотском, в котором издавна велась ее добыча. Биология этого вида на Дальнем Востоке описана в многочисленных публикациях отечественных и зарубежных исследователей (Арсеньев, 1939; Клейненберг и др., 1964; Hazard, 1988; Vergara and Barrett-Lennard, 2008; Бурдин и др., 2009; Шпак и др., 2010; Мещерский и др., 2012; Литовка и др., 2013). Прекращение промысла белухи к середине XX в. привело к значительному сокращению исследований и, как следствие, числа публикаций, посвящённых этому виду.

* Гущеров Павел Сергеевич, исполняюший обязанности заведующего лабораторией, e-mail:paveljuve@mail.ru.

Gushcherov Pavel S., acting head of laboratory,e-mail: paveljuve@mail.ru. 
С 1982 г. ТИНРО-центр проводит работы по отлову, передержке, транспортировке и последующему содержанию в неволе белухи. Несмотря на накопленный опыт содержания морских млекопитающих в неволе, совершенствование методов содержания и ухода за ними остается одной из главных задач таких исследований, позволяющих получить новую достоверную информацию, отражающую специфические черты биологии вида.

Особого внимания в рамках комплексного изучения вида заслуживает исследование его дыхания. Большой интерес к этому определяется тем, что дыхательная система у морских млекопитающих характеризуется целым комплексом выраженных морфофункциональных особенностей (Морские млекопитающие ..., 2010), изучение которых позволяет выявить физиологическое состояние животных.

Дыхательный ритм, характеризуемый частотой дыхания и дыхательной паузой (апноэ), зависит от многих факторов - пола и возраста животных, состояния их организма, двигательной активности и условий окружающей среды, которые подробно описаны у дельфина-афалины (Колчинская и др., 1980).

Частично аналогичные сведения опубликованы и по белухе, содержащейся в неволе (Коваль и др., 1986; Дорошенко, Дорошенко, 2008; Чечина, Кондратьева, 2009; Дорошенко и др., 2010; Дорошенко, 2011; Лямин и др., 2011; Тюпелеев и др., 2011; Гущеров, 2012a, б; Кузин и др., 2012). Однако они недостаточны и фрагментарны.

В настоящей работе приводятся новые данные о дыхательном ритме белух, содержащихся в условиях неволи в дельфинарии ТИНРО-центра.

\section{Материалы и методы}

Объектами исследований были белухи, отловленные в Сахалинском заливе Охотского моря в 2009-2012 гг., которые содержались в дельфинарии ТИНРО-центра (табл. 1).

Таблица 1

Характеристика исследуемых белух

Table 1

Characterization of white whales in the study

\begin{tabular}{|c|c|c|c|c|c|}
\hline Дата отлова & Кличка & Пол & $\begin{array}{c}\text { Длина тела, } \\
\text { см } \\
\end{array}$ & Окраска тела & $\begin{array}{c}\text { Приблизительный } \\
\text { возраст, годы }\end{array}$ \\
\hline 22.07.2009 г. & Кема & q & 320 & Серая & 5 \\
\hline 09.08.2010 г. & Тайфун & $\hat{0}$ & 310 & Светло-серая & 5 \\
\hline 03.09.2010 г. & Дар & $\hat{0}$ & 300 & Серая & 3 \\
\hline 25.06.2011 г. & Тина & 운 & 250 & Серая & 2 \\
\hline 10.07.2011 Г. & Бублик & $\hat{0}$ & 300 & Голубая & 3 \\
\hline 17.07.2011 г. & Буся & $q$ & 250 & Серая & 2 \\
\hline 23.06.2012 г. & Майя & q & 240 & Серая & 2 \\
\hline
\end{tabular}

Сбор материала осуществлялся методом визуальных наблюдений: утром - с 9 до 10 час, днём — с 13 до 14 и вечером — с 16 до 17 час.

При исследовании внешнего дыхания белух проводился также учет частоты дыхания и дыхательной паузы (апноэ).

Обращали внимание на всплытие животного на поверхность воды и движение непарного носового отверстия - дыхала, которое обеспечивает реализацию актов выдоха/вдоха. Задержка дыхания (апноэ) учитывалась от момента выдоха/вдоха при погружении животного под воду и до выдоха/вдоха при всплытии его на поверхность. В течение 10 мин с помощью секундомера, индивидуально, регистрировались количество актов выдоха/вдоха и длительность дыхательных пауз. Оценка внешнего дыхания проводилась путём вычисления средней статистической частоты дыхания (с ошибкой средней) и максимальной дыхательной паузы - МдП. Возраст у белух определялся по размеру и окраске тела (Дорофеев, Клумов, 1935).

Методика определения двигательной активности белух была сформирована по результатам ежегодных наблюдений. Выделено 5 типов локомоторной активности, которые были ранжированы по степени нарастания увеличения локомоции, с присвоением 
им соответствующего балла: 1 - незначительные движения головой и ластами; 2 покачивание, притапливание, повороты тела на месте; 3 - медленные перемещения по вольеру со скоростью $0,3-0,9$ м/с; 4 - перемещение с незначительной скоростью 1,0-2,5 м/с; 5 - быстрые движения со скоростью более 3 м/с, выпрыгивание из воды, верчение и т.п.

Статистическая обработка полученных результатов проводилась стандартными методами с использованием программ Exel и Statistica for Windows.

\section{Результаты и их обсуждение}

Дыхание белух при адаптации к условиям неволи. Предыдущие исследования показали, что отлов и содержание в условиях неволи для белух и других китообразных являются стресс-факторами, изменяющими их физиологическое состояние, в том числе и характеристики дыхания (Белькович, Гуревич, 1971). Так, например, в условиях неволи при плохом состоянии здоровья у дельфина-белобочки Delphinus delphis частота дыхания в среднем составляла 6,2 дых./мин, а после лечения - 3,0 дых./мин (Белькович, Гуревич, 1971).

Известно, что все китообразные в среднем делают около 3-8 выдохов/вдохов в минуту (Slijper, 1962). Естественно, что для разных видов в определенной природной обстановке дыхание различается.

Согласно литературным данным, у белух частота дыхания варьирует в пределах 3-4 дых./мин (Колчинская и др., 1980) с дыхательной паузой 0,3-5,0 мин, а иногда до 15 мин (Клейненберг и др., 1964; Яблоков и др., 1972).

В 2011-2012 гг. нами проведены последовательные наблюдения за дыханием самки Тины (табл. 1) при адаптации к условиям неволи после поимки на о. Чкалова, при транспортировке и дальнейшем содержании в условиях дельфинария (бухта Средняя).

В первые дни после отлова самка Тина совершала в основном стереотипные циклические движения - по кругу внутри садка. Такой тип движения характерен для животных, находящихся под влиянием стресса (Крушинская, Лисицына, 1983). Это состояние белухи отразилось на её дыхании (рис. 1). Средние показатели СЧД в этот период составляли 2,2 \pm 0,3 дых./мин, а МДП - 1,7 мин.

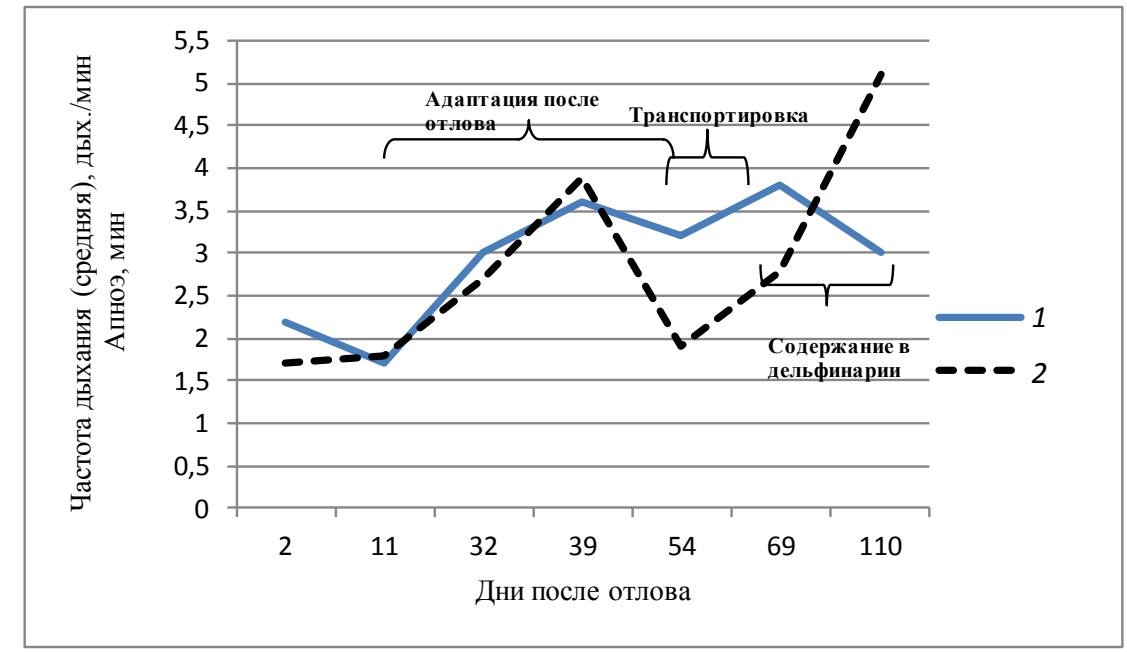

Рис. 1. Изменение дыхательного ритма самки Тины с момента ее отлова: 1 - средняя частота дыхания; 2 - максимальная дыхательная пауза

Fig. 1. Change of respiratory rhythm for Tina female since its capture: 1 - mean respiration rate; 2 - maximum apnea

На 39-й день после отлова показатели дыхания у этой самки увеличились: СЧД 3,6 \pm 0,6 дых./мин и МДП - 3,9 мин. Животное уже начало брать рыбу из рук мастера по адаптации. 
На 54-й день самку транспортировали в ванне на научно-исследовательском судне «Бухоро» в течение 5 дней. Её показатели дыхания в эти дни составили: СЧД $-3,2 \pm 0,3$ дых./мин, МДП - 1,9 мин.

На 69-й день после отлова самка Тина содержалась в условиях дельфинария. Показатели ее дыхания на тот момент составляли: СЧД - 3,8 $\pm 0,2$ дых./мин, МДП - 2,8 мин. Спустя 3 мес. после отлова параметры внешнего дыхания у нее приобрели следующие значения: СЧД - 3,0 0 0,2 дых./мин, МДП - 5,1 мин.

Таким образом, анализ полученных материалов показывает, что в первые дни после отлова дыхание у белух характеризуется низкими значениями показателей — частоты дыхания и апноэ. В течение последующих 10-34 дней показатели параметров внешнего дыхания возрастают и становятся близки к значениям, описанным в литературе (Клейненберг и др., 1964; Яблоков и др., 1972; Колчинская и др., 1980) на животных в природных условиях.

Изменение частоты дыхания в зависимости от двигательной активности

белух. Известно, что частота дыхания у дельфинов определяется их двигательной активностью (Колчинская и др., 1980). В свою очередь, двигательная активность является объективным признаком, свидетельствующим о состоянии здоровья животных (Белькович, Гуревич, 1969).

Содержание морских млекопитающих в ограниченных пространствах дельфинариев связано с определенным состоянием двигательной активности (гипокинезия, гиподинамия), которое может привести к существенному снижению функций нервной системы (Дорошенко, Дорошенко, 2008).

По данным А.Н. Дорошенко (Дорошенко, Дорошенко, 2008; Дорошенко, 2011), наиболее высокая двигательная активность у белух отмечена в утренние часы. Наши исследования показали, что высокая двигательная активность (ДА) встречается в первой половине дня, однако непродолжительно. Всплески высокой ДА в 5 баллов отмечаются в течение всей первой половины дня, но они недлительные и отмечаются редко (табл. 2). ДА в 4 балла у белух чаще наблюдалась в дневное время. В среднем в течение суток ДА составляет 2-3 балла.

Таблица 2

Соотношение типов двигательной активности (ДА) белух в разное время суток, \%

Types of motor activity (ДА) for white whales at different times of the day, $\%$

Table 2

\begin{tabular}{|c|c|c|c|}
\hline ДА, баллы & Утро & День & Вечер \\
\hline 1 & 3,9 & 0 & 5,9 \\
\hline 2 & 22,7 & 11,8 & 4,9 \\
\hline 3 & 10,8 & 13,8 & 4,9 \\
\hline 4 & 6,9 & 11,7 & 0,9 \\
\hline 5 & 0,9 & 0,9 & 0 \\
\hline Всего & $\mathbf{4 5 , 2}$ & $\mathbf{3 8 , 2}$ & $\mathbf{1 6 , 6}$ \\
\hline
\end{tabular}

При ДА белух в 1 балл средняя частота дыхания достигает $3,2 \pm 0,8$ дых./мин, а продолжительность дыхательной паузы - 2,4 мин (рис. 2). При ДА в 2 балла СЧД составила 4,0 \pm 0,5 дых./мин, а апноэ - 1,2 мин. Показатель СЧД 5,1 \pm 0,4 дых./мин с дыхательной паузой 0,4 мин был зарегистрирован у белух с ДА в 3 балла. При ДА в 4 балла средняя частота дыхания возрастает (по сравнению с относительным покоем) до $6,8 \pm 0,4$ дых./мин с апноэ 0,3 мин. При 5 баллах двигательной активности СЧД составляет 4,0 \pm 0,3 дых./мин с дыхательной паузой 0,7 мин.

Изменение частоты дыхания в зависимости от возраста белух. У дельфиновафалин, так же как и у наземных животных, в середине второго месяца жизни происходит учащение дыхательного ритма, сменяемое к 2-летнему возрасту его урежением (олигопноэ). При старении появляется тенденция к учащению дыхания. Величина возрастных изменений дыхательного ритма у дельфинов статистически достоверна (Колчинская и др., 1980). Аналогичное явление наблюдается у детенышей наземных животных, обладающих меньшими размерами тела и более высокой интенсивностью 


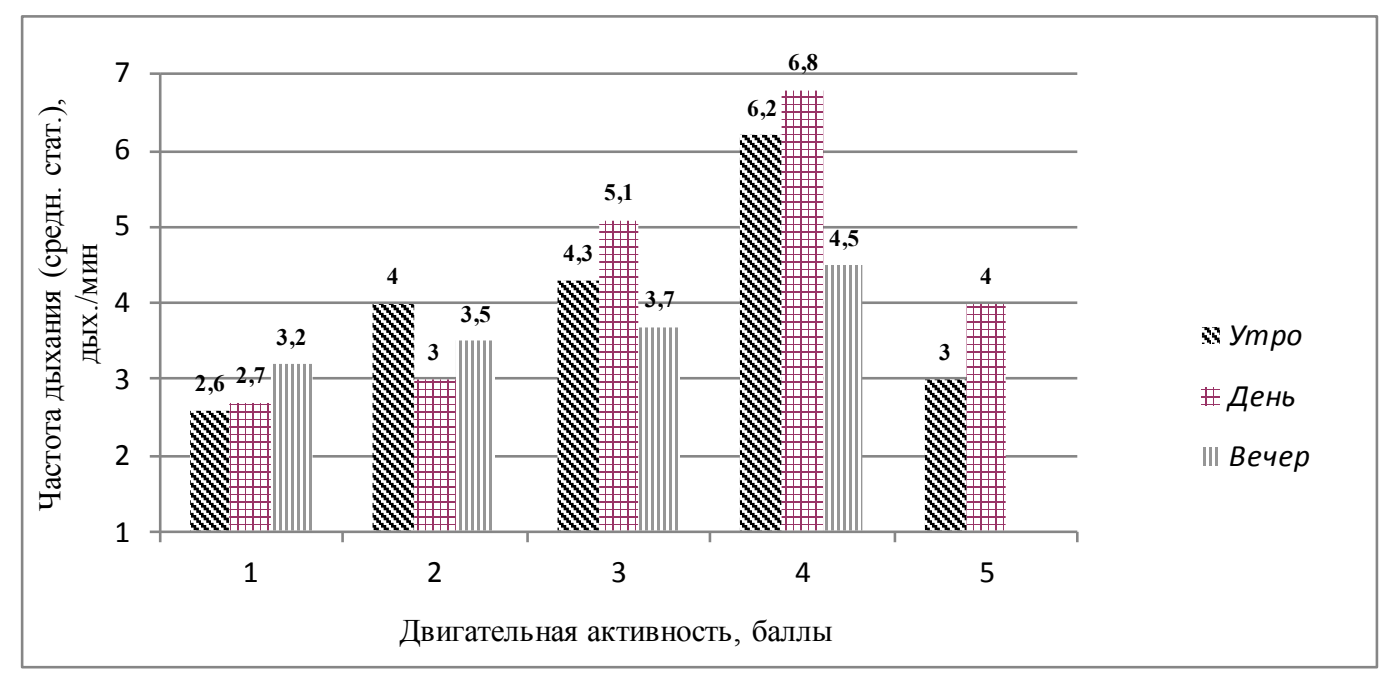

Рис. 2. Изменение частоты дыхания в зависимости от двигательной активности белух

Fig. 2. Change of respiration rate for white whales in dependence on their motor activity

окислительных процессов, соответственно частота дыхания у них выше, чем у половозрелых особей (Колчинская и др., 1980).

Проведенные нами исследования показали, что у белух в возрасте 2 лет частота дыхания и апноэ выше, чем у животных 3- и 5-летнего возраста (рис. 3). Полученные результаты совпадают с тем, что в более позднем возрасте обнаруживается тенденция к учащению дыхания. К сожалению, в нашей выборке не было животных старше 5 лет. Однако в связи с тем что дыхание у белух более частое, чем у дельфинов, величина возрастных изменений выше.

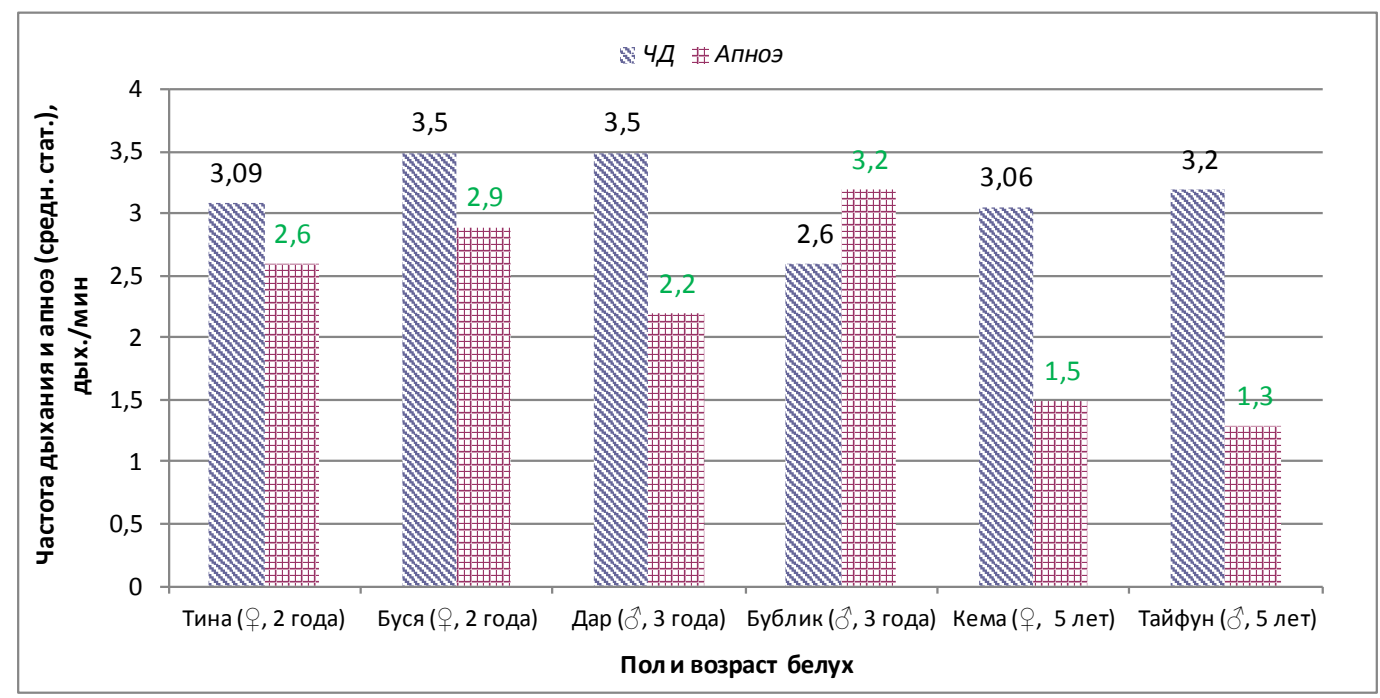

Рис. 3. Изменение показателей дыхания в зависимости от пола и возраста белух

Fig. 3. Change of respiration rate for white whales in dependence on their sex and age

Влияние температуры воды на частоту дыхания белух. Температура воды является одним из факторов, оказывающих влияние на частоту дыхания морских млекопитающих. У дельфинов афалин при температуре воды $8-9{ }^{\circ} \mathrm{C}$ частота дыхания достигает $3,40 \pm 0,10$ дых./мин, а при $23^{\circ} \mathrm{C}-2,05$ дых./мин (Колчинская и др., 1980).

Проведенные нами исследования показали, что в зимнее время года, когда температура воды опускается ниже нуля, двигательная активность у белух повыша- 
ется. Такое поведение очень важно для регуляции температуры тела теплокровных животных, оно называется «поведенческой терморегуляцией» (Ткаченко, 2005). При интенсивных движениях у белух происходит ускорение окислительных процессов, за счет чего увеличивается частота дыхания. Зимой при температуре воды минус $2,5{ }^{\circ} \mathrm{C}$ СЧД у белух равнялась $3,3 \pm 0,2$ дых./мин. При температуре воды плюс $2{ }^{\circ} \mathrm{C}$ частота дыхания увеличивалась до 3,50 $\pm 0,08$ дых./мин.

В весеннее время, при достижении плюсовой температуры воды, двигательная активность у белух снижается, соответственно дыхание становится реже. Наблюдения показали, что при температуре воды $0{ }^{\circ} \mathrm{C}$ частота дыхания составляет $3,1 \pm 0,1$ дых./мин. $\mathrm{C}$ повышением температур до 2 и $8{ }^{\circ} \mathrm{C}$ частота дыхания у белух уменьшается соответственно до $3,0 \pm 0,1$ и 2,9 $\pm 0,1$ дых./мин.

Дыхание белух в утреннее и вечернее время. В литературе (Колчинская и др., 1980) упоминается, что у дельфинов-афалин в неволе частота дыхания зависит от времени суток. Согласно нашим наблюдениям, СЧД белух в утренние часы изменяется в пределах 1,8-5,0 дых./мин (рис. 4). Наибольшие значения этого показателя зарегистрированы у самки Буси - 5,0 $\pm 1,0$ дых./мин. Длительность МДП у неё в утреннее время изменялась от 1,8 до 6,4 мин (рис. 5).

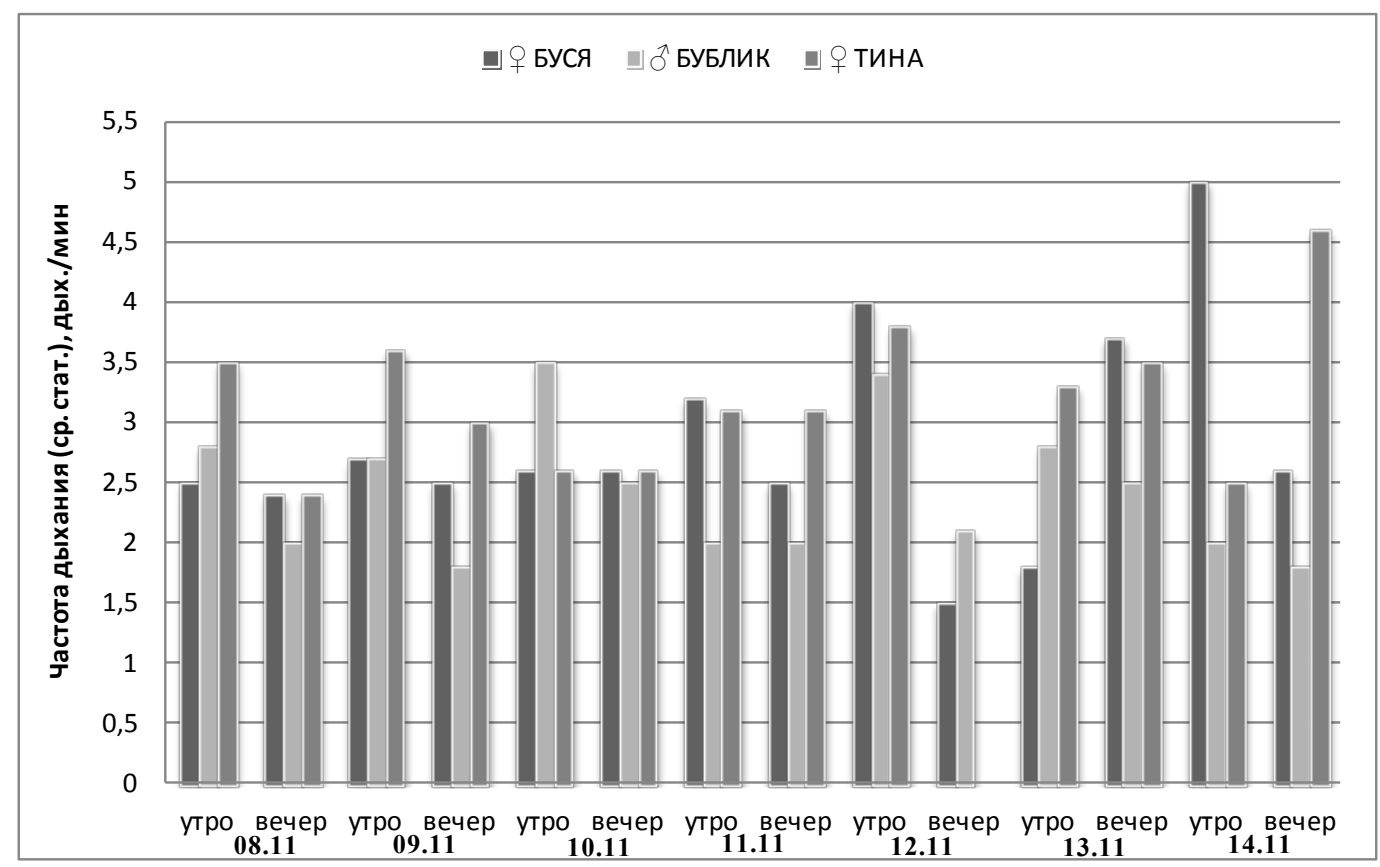

Рис. 4. Частота дыхания белух в разное время суток

Fig. 4. Respiration rate of white whales at different times of the day

В вечернее время СЧД белух варьировала в пределах 1,5-4,6 дых./мин (см. рис. 4). Максимальное значение СЧД - 4,6 $\pm 1,3$ дых./мин - отмечено у самки Тины. Длительность МДП в вечернее время составляла 1,4-6,3 мин (см. рис. 5).

Наши наблюдения показали, что дыхание белух в утренние часы до кормления несколько учащенно по сравнению с вечерним временем (Гущеров, 2012a). Аналогичная ситуация отмечалась у дельфинов-афалин в неволе (Колчинская и др., 1980).

\section{Заключение}

Проведенные исследования показали, что во время адаптации белух к условиям неволи одним из основных внешних показателей состояния их здоровья являются параметры внешнего дыхания. Выявлено, что в первые дни после отлова у белух наблюдается паттерн дыхания, характеризующийся низкими значениями показателей - частоты дыхания и апноэ (СЧД - 2,2 \pm 0,3 дых./мин, МДП - 1,7 мин). 


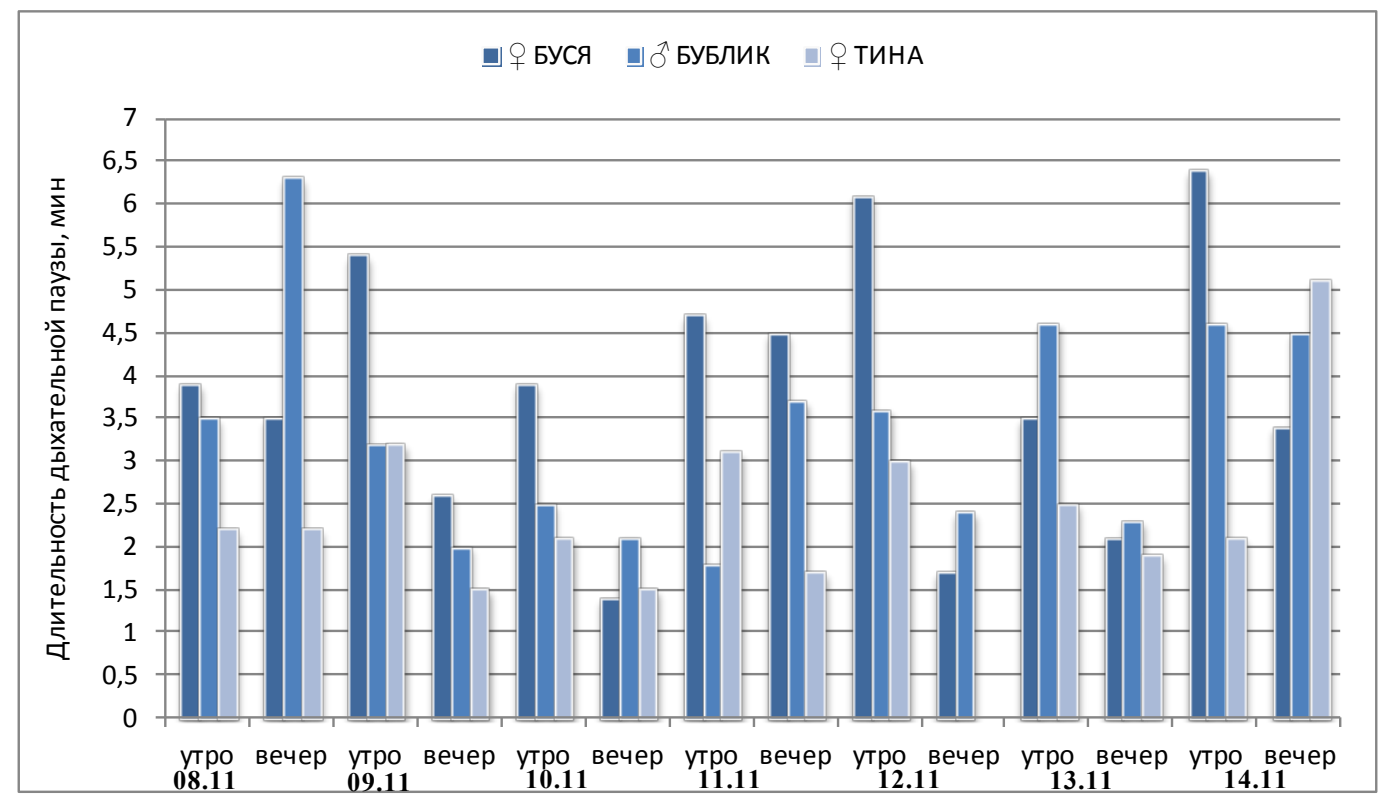

Рис. 5. Дыхательная пауза (апноэ) белух в разное время суток

Fig. 5. Breathing pause (apnea) of white whales at different times of the day

В течение последующих 10-34 дней показатели параметров внешнего дыхания приближаются к норме (СЧД - 3,0 \pm 0,2 дых./мин, МДП - 5,1 мин).

Результаты исследований выявили четкую зависимость частоты дыхания животных от их двигательной активности. Например, при слабой двигательной активности (1 балл) СЧД составляла 3,2 $\pm 0,8$ дых./мин, а при высокой (5 баллов) - 4,0 $\pm 0,3$ дых./мин.

Определены некоторые различия в частоте дыхания и апноэ у белух разного возраста: у животных в возрасте 2 лет частота дыхания и апноэ достигали $3,5 \pm 0,2$ дых./мин и 2,9 мин. В 5-летнем возрасте аналогичные показатели имели более низкие значения (3,06 $\pm 0,10$ дых./мин и 1,5 мин).

Установлено, что влияние на частоту дыхания белух оказывает температура воды. Зимой, при температуре воды ниже минус $2{ }^{\circ} \mathrm{C}$, частота дыхания у белух составляла 3,5 дых./мин, а в весеннее время при температуре воды $8{ }^{\circ} \mathrm{C}$ снизилась до 2,9 дых./мин. Это объясняется в первую очередь тем, что в зимнее время года двигательная активность у белух выше, чем весной.

Наши наблюдения подтверждают, что дыхание белух в утренние часы несколько учащенно по сравнению с вечерним временем. Возможно, что повышенная частота дыхания у белух утром связана с тем, что в условиях неволи они питаются регулярно, по графику. Общее возбуждение животных в часы, предшествующие кормлению, приводит к повышенной двигательной активности, что и обусловливает высокие значения частоты дыхания в утренние часы.

Таким образом, приведенные выше результаты указывают, что информация о параметрах внешнего дыхания белух является важным показателем их физиологического состояния и должна обязательно учитываться в комплексе с другими мероприятиями при содержании животных в условиях неволи.

Автор выражает глубокую благодарность за иченные замечания и советы д-ру биол. наук, профессору В.П. Шунтову, канд. биол. наук П.А. Тюпелееву, канд. биол. наук А.Е. Кузину. Также автор признателен за помощь при сборе материалов в 2009-2012 г2. старшему матросу С.В. Макраку, заведующему сектором адаптации морских млекопитающих И.А. Набережных. Искренне признателен всем сотрудникам лаборатории морских млекопитающих ТИНРО-цеентра за постоянную техническую помощь и поддержку. 


\section{Список литературы}

Арсеньев В.А. Распределение и миграции белухи на Дальнем Востоке : Изв. ТИНРО. 1939. - T. $15 .-108 \mathrm{c}$.

Белькович В.М., Гуревич В.С. Вопросы отлова и длительного содержания дельфинов в неволе // Тр. АтлантНИРО. - 1971. - Вып. 34. - С. 286-295.

Белькович В.М., Гуревич В.С. Отлов, транспортировка и медицинское обслуживание дельфинов // Тез. докл. Четвертого Всесоюз. совещ. по изучению морских млекопитающих. М., 1969. - С. 91-96.

Бурдин А.М., Филатова О.А., Хойт Э. Морские млекопитающие России : справочникопределитель. - Киров : Кировская областная типография, 2009. - 208 с.

Гущеров П.С. Дыхательный ритм белух (Delphinapterus leucas) в условиях неволи // Мат-лы 11-й регион. конф. студентов, аспирантов вузов и науч. организаций Дальнего Востока России. - Владивосток : ДВФУ, 2012а. - С. 58-60.

Гущеров П.С. Параметры внешнего дыхания как экспресс-тест для определения физиологического состояния белух (Delphinapterus leucas Pallas, 1776) // Морские млекопитающие Голарктики : сб. науч. тр. по мат-лам 7-й междунар. конф. - Суздаль, 2012б. - Т. 1. - С. 213-215.

Дорофеев С.В., Клумов С.К. К вопросу об определении возраста белухи и состава косяков // Тр. ВНИРО. - 1935. - Т. 3. - С. 24-34.

Дорошенко А.Н. Динамика гематологических и респираторных показателей физиологического состояния дальневосточной белухи (Delphinapterus leucas Pallas, 1776) при отлове и адаптации к условиям неволи // Изв. Самар. науч. центра РАН. Биологические ресурсы: фауна. — 2011. — T. 13, № 1(5). - С. 1079-1082.

Дорошенко М.А., Дорошенко А.Н. Исследование параметров внешнего дыхания и двигательной активности дальневосточной белухи (Delphinapterus leucas dorofeevi Klumov et Barabasch, 1935) при содержании в дельфинарии // Морские млекопитающие Голарктики : сб. науч. тр. по мат-лам 5-й междунар. конф. - Одесса, 2008. — С. 160-162.

Дорошенко М.А., Дорошенко А.Н., Лебедева И.Е. Изменение гематологических показателей дальневосточной белухи (Delphinapterus leucas Pallas 1776) под влиянием стресс-факторов (отлов, транспортировка) // Морские млекопитающие Голарктики : сб. науч. тр. по мат-лам 6-й междунар. конф. - Калининград, 2010. - С. 187-191.

Клейненберг С.Е., Яблоков А.В., Белькович В.М., Тарасевич М.Н. Белуха. Опыт монографического исследования вида : моногр. - М. : Наука, 1964. — 456 с.

Коваль Е.3., Бобков А.В., Белозеров И.А. Поведение в неволе и некоторые вопросы обучения морских млекопитающих : отчёт о НИР / ТИНРО. № 20051. - Владивосток, 1986. — 46 с.

Колчинская А.З., Маньковская И.Н., Мисюра А.Г. Дыхание и кислородные режимы организма дельфинов : моногр. - Киев : Наук. думка, 1980. — 332 с.

Крушинская Н.Л., Лисицына Т.Ю. Поведение морских млекопитающих : моногр. - М. : Наука, 1983. - 336 с.

Кузин А.Е., Блохин С.А., Литовка Д.И. и др. Результаты исследования морских млекопитающих в 2012 году : отчет о НИР / ТИНРО-центр. № 27270. - Владивосток, 2012. — 95 с.

Литовка Д.И., Андронов П.Ю., Батанов Р.Л. Оценка сезонного распределения белухи Delphinapterus leucas и объектов ее питания в прибрежных водах северо-западной части Берингова моря // Исслед. вод. биол. ресурсов Камчатки и сев.-зап. части Тихого океана. - Петропавловск-Камчатский : КамчатНИРО, 2013. - Вып. 28. - С. 50-71.

Лямин О.И., Корнева С.М., Рожнов В.В., Мухаметов Л.М. Изменение сердечного ритма и дыхания белухи во время действия акустического шума // Докл. РАН. — 2011. — Т. 440, № 5. - С. 704-707.

Мещерский И.Г., Шпак О.В., Глазов Д.М. и др. Белуха (Delphinapterus leucas) в морях Дальнего Востока: состав и распределение митохондриальных линий // Морские млекопитающие Голарктики : сб. науч. тр. по мат-лам 7-й междунар. конф. — Суздаль, 2012. — Т. 2. — С. 90-94.

Морские млекопитающие в биотехнических системах двойного назначения : метод. пособие / Г.Г. Матишов, В.Б. Войнов, Е.В. Вербицкий и др. - Мурманск : ММБИ КНЦРАН, 2010. - 131 с.

Ткаченко Б.И. Нормальная физиология человека : учеб. - М. : Медицина, 2005. — 928 с.

Тюпелеев П.А., Гущеров П.С., Якимов Р.В. Результаты исследования биологии и этологии белухи (Delphinapterus leucas, Pallas 1776) в 2011 году : отчет о НИР / ТИНРО-центр. № 23755. - Владивосток, 2011. - 53 с.

Чечина О.Н., Кондратьева Н.Л. Вариации дыхательного ритма у детенышей афалины в раннем постнатальном периоде // Уч. зап. Таврич. нац. ун-та. Серия «Биология, химия». 2009. - Вып. 4. - С. 231-235. 
Шпак О.В., Эндрюс Р.Д., Глазов Д.М. и др. Сезонные миграции охотоморских белух Delphinapterus leucas летнего сахалинско-амурского скопления // Биол. моря. — 2010. — Т. 36, № 1. - C. $56-62$.

Яблоков А.В., Белькович В.М., Борисов В.И. Киты и дельфины : моногр. - М. : Наука, 1972. - 472 с.

Hazard K. Beluga whale (Delphinapterus leucas) // Selected marine mammals of alaska: species accounts with research and management recommendation / ed. J.W. Lentfer. - Washington : US Marine Mammal Commision, 1988. - P. 195-235.

Slijper E.J. Whales. - L. : Hutchinson, 1962. — 475 p.

Vergara V. and Barrett-Lennard L.G. Vocal development in a beluga calf (Delphinapterus leucas) // Aquat. Mamm. — 2008. — Vol. 34, Iss. 1. — P. 123-143.

Поступила в редакияию 11.02.16 г. 